\title{
Nutrient production from dairy cattle manure and loading on arable land
}

\author{
Seunggun Won ${ }^{1, a}$, Soo-Min Shim ${ }^{2, a}$, Byung-Gu You ${ }^{2}$, Yoon-Seok Choi ${ }^{2}$, and Changsix Ra $^{2, *}$
}

* Corresponding Author: Changsix Ra Tel: +82-33-250-8618, Fax: +82-33-251-7719,

E-mail: changsix@kangwon.ac.kr

'Department of Animal Resources, College of Life \& Environmental Science, Daegu University, Gyeongsan 38453, Korea

${ }^{2}$ Division of Animal Resource Sciences, College of

Animal Life Science, Kangwon National University,

Chuncheon 24341, Korea

a These authors contributed equally to this work. Submitted Jun 10, 2016; Revised Jul 19, 2016; Accepted Aug 3, 2016
Objective: Along with increasing livestock products via intensive rearing, the accumulation of livestock manure has become a serious issue due to the fact that there is finite land for livestock manure recycling via composting. The nutrients from livestock manure accumulate on agricultural land and the excess disembogues into streams causing eutrophication. In order to systematically manage nutrient loading on agricultural land, quantifying the amount of nutrients according to their respective sources is very important. However, there is a lack of research concerning nutrient loss from livestock manure during composting or storage on farms. Therefore, in the present study we quantified the nutrients from dairy cattle manure that were imparted onto agricultural land.

Methods: Through investigation of 41 dairy farms, weight reduction and volatile solids (VS), total nitrogen (TN), and total phosphorus (TP) changes of dairy cattle manure during the storage and composting periods were analyzed. In order to support the direct investigation and survey on site, the three cases of weight reduction during the storing and composting periods were developed according to i) experiment, ii) reference, and iii) theoretical changes in phosphorus content $(\Delta \mathrm{P}=0)$.

Results: The data revealed the nutrient loading coefficients (NLCs) of VS, TN, and TP on agricultural land were $1.48,0.60$, and 0.66 , respectively. These values indicated that the loss of nitrogen and phosphorus was $40 \%$ and $34 \%$, respectively, and that there was an increase of VS since bedding materials were mixed with excretion in the barn.

Conclusion: As result of nutrient-footprint analyses, the amounts of TN and TP particularly entered on arable land have been overestimated if applying the nutrient amount in fresh manure. The NLCs obtained in this study may assist in the development of a database to assess the accurate level of manure nutrient loading on soil and facilitate systematic nutrient management.

Keywords: Dairy Cattle Manure, Composting, Weight Reduction, Nutrient Loss, Nutrient Loading Coefficients

\section{INTRODUCTION}

Livestock industries have grown tremendously in recent decades to meet the demand from the increasing human population. Improved technologies are also adopted for feeding, breeding, and reproductive management to increase livestock production. A significant amount of manure is produced in addition to meat and milk, which directly relates to concerns of environment conservation. The current increases both quantitative and qualitative living standards have led to additional livestock breeding and the subsequent release of greenhouse gases from manure has contributed to climate change, which has received significant attention in the last decade. Livestock manure is largely composed of organic compounds including nitrogen $(\mathrm{N})$ and phosphorus $(\mathrm{P})$ which results in eutrophication of nearby streams when 
released without an appropriate treatment [1]. Both $\mathrm{P}$ and $\mathrm{N}$ enhance algal blooms in water bodies (rivers, lakes, and seas) worldwide, which reduce light penetration and available oxygen in these ecosystems, and globally has led to the death of aquatic organisms [2].

The nutrient balance in Organisation for Economic CoOperation and Development (OECD) was calculated by the term of the gross $\mathrm{N}$ budget which takes into account the entire nutrients including the risk of air, soil and water pollution. This is corresponded with the term of land budget which is one of nutrient budget types including farm and soil budget suggested in nutrient budgets [3]. As per the explanation about nutrient budget, land budget facilitates the measurement of nutrients including all the influences to the nature using model calculations based on manure and fodder production. Farm budget is the most desirable method but has difficulties to survey each farm. Although soil budget requires also data collection, it is relatively available and meaningful to estimate nutrients on soil excluding $\mathrm{N}$ volatilized and describe nutrients in regional level. Further, the current OECD stat for nutrient balance may not be applicable for some specific countries with lack of grazing land for livestock breeding like Korea. The manure management is mostly separated where its production and application places are. The most part of manure is stored and treated for compost production by livestock farm and then those are applied to cultivated land. Therefore, data collection for soil budget may be relatively facilitated which can be more accurate and reasonable method for the measurement of nutrient balances.

Composting methods in solid and liquid phases play an important role in circulation of nutrients in manure and can affect as much as $88.7 \%$ of the total livestock manure produced in Korea [4]. The sustainable agriculture practices supported by the government ideally aim to obtain a balance of resources in nature through their circulation, whereby nutrients in livestock manure compost are applied to soil to enhance the growth of plants that fed to livestock. Thus, the ultimate goal is to sustainably recycle nutrients in the eco-system that are produced by agricultural practices [5].
Nutrient turnover in manure with or without bulking agents occurs during storage due to the microbial activity [6]. In particular, $\mathrm{N}$ exists in various forms (nitrite/nitrate, nitrous oxide, and nitrogen gas) and its concentration can vary due to ammonia volatilization, nitrification, and denitrification. During these processes, the nitrous oxide and $\mathrm{N}$ gas released to the atmosphere contributes to global warming. About $20 \%$ to $40 \%$ of the $\mathrm{N}$ in manure may be lost during the storage and composting processes through gaseous emission [6,7].

Since the calculation of nutrient loading from livestock manure has been achieved based on OECD stat using the number of animals and the excretion coefficients, nutrient application from livestock manure on arable land has been overestimated with respect to soil budget due to neglecting to account for the loss of nutrients during the composting or storing periods. Thus, the practical nutrient loading on soil may be required for accurate and systematic management of livestock manure.

According to the OECD report in 2008, the $\mathrm{N}$ and $\mathrm{P}$ amounts of 224.6 and $44.4 \mathrm{~kg} / \mathrm{ha}$ has been accumulated, respectively, in Korean arable land, which was the highest level among the OECD countries. The N loading in Korea was 583,000 tonnes, of which chemical fertilizer contributed $45 \%$ and livestock manure $49 \%$ in 2009. Chemical fertilizer and livestock manure contributed $42 \%$ and $58 \%$ to the total P loading of 107,000 tonnes, respectively. Based on OECD stat, implementing a nutrient-quota production and limiting the number of animal heads on farms have been proposed and estimated based on the environmental capacity [8] which threats livestock industry.

As mentioned above, $\mathrm{N}$ and $\mathrm{P}$ resources for crop cultivation come mainly from chemical fertilizer and livestock manure compost and their flux in agricultural sector is illustrated (Figure 1). Different from N, P flux mostly comes from phosphate rock and also $\mathrm{P}$ content from livestock manure is originated from feedstock in which P source is provided by phosphate rock. Nutrients provided from livestock manure for crop cultivation can be released to air for $\mathrm{N}$ and soil and water for $\mathrm{P}$ during the storing or composting period.

Although such a nutrient loss may vary dependent on the

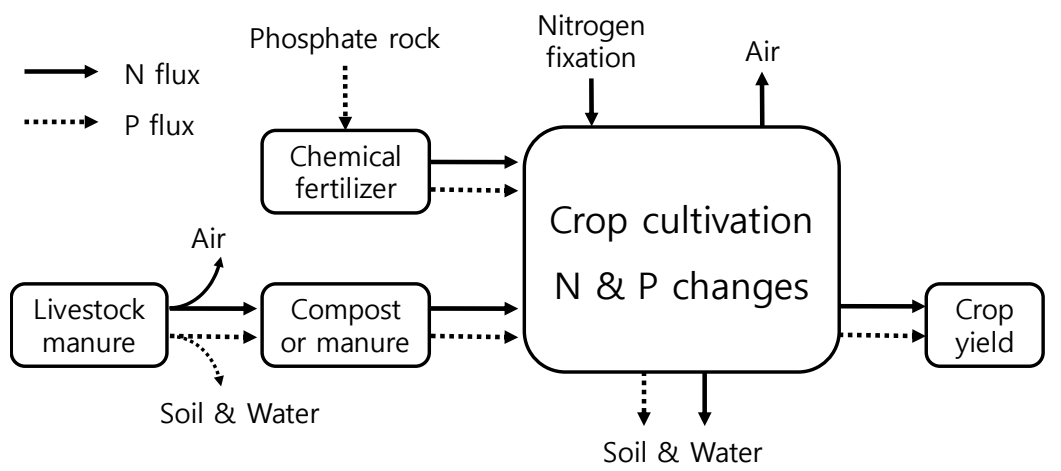

Figure 1. Nutrient ( $N$ and $P$ ) flux in agricultural sector. $N$, nitrogen; $P$, phosphorus. 
traditional manure management, regional climate condition in each region, and livestock categories, quantifying and building up database of soil budget for nutrient may support the systematic management of nutrient and the environmental protection.

Therefore, this study was carried out to investigate the status of dairy cattle manure management and calculate the nutrient loading coefficients (NLCs) with consideration of nutrient loss during the composting or storing of manure. At the same time, the practical nutrient loading on soil from dairy cattle manure was estimated in order to assist in database construction account for nutrient loss from livestock manure, which supports the measurement of soil budget.

\section{MATERIALS AND METHODS}

\section{Farm survey and sample collection}

In order to collect samples and information from dairy farms, basic information was obtained in person regarding breeding heads, bedding materials, excretion structure and the amount of manure production after the 41 farms in Korea was investigated and the contents of $\mathrm{N}$ and $\mathrm{P}$ in those samples were measured. Methods of manure management were also investigated with detailed information recorded. Samples were collected from fresh manure and compost prior to application. For sampling on site, $20 \mathrm{~L}$ bucket was used for collection of fresh manure. However, compost samples were collected in $20 \mathrm{~L}$ bucket from vertical trisection of compost pile with 1 to $1.8 \mathrm{~m}$ of height.

\section{Analytical methods}

Collected samples were stored at $-4^{\circ} \mathrm{C}$ until analysed. For total nitrogen (TN) and phosphorus (TP), samples were mixed with strong acid and heated in the block digester (BD40, LaChat, Milwaukee, WI, USA) at $320^{\circ} \mathrm{C}$. Then, the analyses were conducted using the auto water analyser (QuikChem 8500, LaChat, Loveland, CO, USA). Total solids were determined by comparison of the sample weight before and after drying oven at $105^{\circ} \mathrm{C}$ overnight. The determination of volatile solids (VS) as organic matter was carried out after a high temperature muffle furnace at $550^{\circ} \mathrm{C}$ for over 4 hours [9]. The bulk density of the samples was weight per unit volume, which was measured with $18-\mathrm{L}$ of bucket on site following the methods of Cooperband [10].

Calculation of nutrient loading from dairy cattle manure The nutrient loading refers to the nutrients from dairy cattle manure that released into the environment, specially soil and streams. However, livestock manure passes through a composting or storing period prior to land application. Through the composting or storing period, the oxidation of organic matter and $\mathrm{N}$ stripping or transformation occurs, which leads to a loss of nutrients. Hence, the amount of nutrient loading can be calculated by multiplying the total nutrients in manure with
NLCs, which are considered to account for nutrient loss during the composting or storing period. Hence, NLCs as a dimensionless number represent the opposite of nutrient loss ratio.

$$
\begin{aligned}
& \text { Nutrient loading amount }(\mathrm{kg} \mathrm{VS}, \mathrm{N}, \mathrm{P} / \mathrm{head} / \mathrm{yr}) \\
& =\text { Nutrient con. in manure }(\mathrm{kg} / \mathrm{t}) \\
& \quad \times \text { Manure amount }(\mathrm{t} / \mathrm{head} / \mathrm{yr}) \times \mathrm{NLCs}
\end{aligned}
$$

Where above, NLCs represents nutrient loading coefficients.

The nutrient loss rate during the composting or storing period can be calculated by dividing the nutrient quantities in compost by those of manure.

$$
\begin{aligned}
& \text { Nutrient loss rate }(\%)=\frac{\text { Nutrients in compost }(\mathrm{VS}, \mathrm{N}, \mathrm{P})(\mathrm{mg})}{\text { Nutrients in manure }(\mathrm{VS}, \mathrm{N} \mathrm{P})(\mathrm{mg})} \times 100 \\
& =\frac{\text { Compost product }(\mathrm{kg}) \times \text { Conc. of nutrients in compost }(\mathrm{mg} \mathrm{VS}, \mathrm{N}, \mathrm{P} / \mathrm{kg})}{\text { Manure product }(\mathrm{kg}) \times \text { Conc. of nutrients in manure }(\mathrm{mg} \mathrm{VS}, \mathrm{N}, \mathrm{P} / \mathrm{kg})} \times 100
\end{aligned}
$$

\section{Construction and application of the experiments}

In order to obtain nutrient quantities in compost and manure, the concentrations of VS, TN, and TP were multiplied by the amount of manure and compost, respectively, but the whole quantities of manure could not be measured directly on site. Thus, the value from Ministry of environment displays of 37.7 L/head/d for Holstein was used for NLC calculation [11].

Regardless, the measurement of compost production was not feasible directly on site. Hence, the amount of compost production was assessed after consideration of three different cases to understand nutrient loading after manure production. The first experimental operations were carried out to obtain the weight reduction during the composting or storing period (case I) and were conducted at the research and development ranch of Kangwon National University, South Korea (39 $56^{\prime} \mathrm{N}$, $127^{\circ} 46^{\prime} \mathrm{E}$ ) for 4 months. First, the floors of 3 barns were covered by $15 \mathrm{~cm}$ of sawdust to prevent the cattle from being affected by the cold and also to remove moisture, simulating conditions widely implemented in over $90 \%$ of dairy farms for the management of manure and cattle in Korea. A total of 12 Holstein in growing, milking, or dry stages $(429 \pm 112 \mathrm{~kg}$ of initial body weight) were selected and allocated to barns. Each barn had 4 Holstein, allowing for $6.4,13.5$, and $16.5 \mathrm{~m} 2 /$ head of stocking density for growing, milking and dry stages, respectively, in order to meet national standard for sustainable livestock management [12]. The mixture of manure and sawdust was stepped on and turned over by cows for 3 months, after which the mixture was retrieved from the barns and stored in a compost lot for 1 month. According to the Korean Rural Development Administration, the daily manure production of Holstein was determined to account for $5.6 \%, 6.5 \%$, and $10.3 \%$ of body weight in the growing, milking, and dry stages, respectively, values that were adopted for the calculation of case I. Case II was the reference experiment to determine volume reduction during 
the composting period. Finally, case III was calculated based on the amount of P. One of the important components in nutrients, $\mathrm{P}$, should theoretically not change during the composting period. Practically, however, $\mathrm{P}$ loss during the composting period occurs via run-off and leachate [13], which is additional nutrient loading to the environment, whereby constant amount of $\mathrm{P}$ amount before and after composting can be counted. The concentrations of each nutrient in the manure and compost samples were collected and directly analysed and the amount of $\mathrm{P}$ in manure calculated using the total amount of manure produced based on the documents from Ministry of Environment. The total compost produced was based on the amount and concentration of $\mathrm{P}$ found after analysis of compost samples. Thus, manure production from Ministry of Environment was combined with the results from case II and III in order to calculate NLCs on land.

\section{RESULTS}

\section{Investigation of dairy farms}

The main livestock categories in Korea are beef and dairy cattle, pig, broiler, and layers which produced manure of 44.8 million $\mathrm{m}^{3} / \mathrm{yr}$ in 2013. Ministry of Environment in Korea announced the excretion coefficients in each livestock categories in 2008 and a head of dairy cattle produces manure of $37.7 \mathrm{~L} / \mathrm{d}$. The number of dairy cattle occupied only $3 \%$ of four major livestock categories (Hanwoo, dairy cattle, pig, and chicken) in Korea (the number of chicken was counted in thousandfold) but its manure production contributed $12.9 \%$. In addition, the daily nutrient production of $\mathrm{N}$ and $\mathrm{P}$ in dairy cattle manure are the highest of 161.8 and $56.7 \mathrm{~g} /$ head over the other livestock categories and the yearly nutrient production based on the dairy cattle numbers were $8.0 \%$ and $7.0 \%$ of the $\mathrm{N}$ and $\mathrm{P}$ production from the entire livestock in Korea.

In total 41 dairy farms were selected to investigate manure management and nutrient loading on land as well as farm animal databases. The head of cattle ranged from 12 to 140 with an average of 64, which was less than the average of 75 for all of Korea [14]. All dairy farms used sawdust as the bedding material with the number of time which was replaced ranging from 1 to $8 / \mathrm{yr}$ (average 3.2/yr), and the average consumption of bedding materials per head was $1.03 \mathrm{~kg} / \mathrm{d}$ (Table 1 ). The
Table 1. Methods of manure management and characteristics of 41 dairy farmsinvestigated

\begin{tabular}{lcc}
\hline Contents & Range & Average \\
\hline The number of head per farm & $12-140$ & $64.0 \pm 26$ \\
Exchange rate of bedding materials (turn/yr) & $1-8$ & $3.2 \pm 1.6$ \\
Daily bedding material used (kg/d) & $4-175$ & $66.3 \pm 40.1$ \\
Daily bedding material used per head (kg/head/d) & $0.19-2.11$ & $1.03 \pm 0.52$ \\
Composting methods (\%) & & \\
$\quad$ Turning & 12 & \\
Simple static pile & 88 & \\
\hline
\end{tabular}

thickness of the bedding material was $15 \mathrm{~cm}$ and it was replaced when it reached $60 \%$ to $70 \%$ moisture as determined by the farmers. In relation to composting methods, only $12 \%$ of the entire dairy farms conducted turning using a skid-loader or tractor while the remaining ones heaped simple static piles without any air-supply.

\section{Characteristics of dairy cattle manure and compost}

The samples of manure and compost collected from the 41 dairy farms were analysed to determine the total VS, TN, and $\mathrm{TP}$ and to calculate the amount of each nutrient in each (Table 2). The $\mathrm{TN}$ concentration $(5,086 \mathrm{mg} / \mathrm{kg})$ in manure was close to that from Ministry of Environment $(5,203 \mathrm{mg} / \mathrm{kg})$, while the TP concentration was much lower $(1,289 \mathrm{mg} / \mathrm{kg})$ than the Ministry of Environment value $(1,823 \mathrm{mg} / \mathrm{kg})$. On the other hand, a much higher concentration of TN $(8,897 \mathrm{mg} / \mathrm{kg})$ and TP $(2,186 \mathrm{mg} / \mathrm{kg})$ was found in samples collected from the composting lot. The VS content of $10.8 \%$ in manure increased to $21.4 \%$ when manure was housed in the barn and composting. This was probably because the bedding materials such as sawdust and rice husk mostly counted as VS were mixed with manure even though the VS was degradable during the storage and composting periods.

\section{Assessment of weight reduction cases during the composting period}

As previously described, the cases for weight reduction of dairy manure were calculated. In order to obtain practical values for Case I, the measurements were conducted in two stages; i.e., the excretion from cattle was housed in the barn and rolled with bedding materials for 3 months, after which point the mixture

Table 2. Nutrient concentrations of dairy cattle manure and compost according to on farm investigation and the reports from the Ministry of Environment in Korea

\begin{tabular}{|c|c|c|c|c|c|}
\hline \multirow{2}{*}{ Source of values } & \multicolumn{3}{|c|}{ Concentration (mg/kg) } & \multirow{2}{*}{ Moisture content (\%) } & \multirow{2}{*}{$\begin{array}{l}\text { Bulk density } \\
\quad\left(\mathrm{kg} / \mathrm{m}^{3}\right)\end{array}$} \\
\hline & VS (\%) & TN & TP & & \\
\hline$M E^{1)}$ & - & 5,203 & 1,823 & - & - \\
\hline Fresh manure ${ }^{2)}$ & $10.8 \pm 1.4$ & $5,086 \pm 1,743$ & $1,289 \pm 457$ & $81.6 \pm 4.6$ & $998.7 \pm 74.8$ \\
\hline Compost & $21.4 \pm 5.1$ & $8,897 \pm 4,947$ & $2,186 \pm 1,383$ & $69.0 \pm 10.1$ & $791.0 \pm 207.0$ \\
\hline
\end{tabular}

VS, volatile solids; TN, total nitrogen; TP, total phosphorus

${ }^{1)} \mathrm{ME}$, the values from Ministry of Environment in Korea.

${ }^{2)}$ The sample was collected from the barn avoiding bedding materials. 
Table 3. Experimental weight reduction of dairy cattle manure in dairy cattle barn and composting lot after 4 months

\begin{tabular}{lccccccc}
\hline Stall number & $\begin{array}{c}\text { Manure production Bedding materials } \\
(\mathbf{k g})(\mathbf{A})\end{array}$ & $\begin{array}{c}\text { Mixture weight } \\
(\mathbf{k g})(\mathbf{B})\end{array}$ & $\begin{array}{c}\text { Weight loss-1) } \\
(\mathbf{k g})\end{array}$ & $\begin{array}{c}\text { Mixture weight } \\
(\mathbf{k g})(\mathbf{D})\end{array}$ & $\begin{array}{c}\text { Weight loss-2) } \\
(\%)\end{array}$ & $\begin{array}{c}\text { Total weight loss } \\
(\%)\end{array}$ \\
\hline 1 & 5,880 & 667 & 2,476 & 62.2 & 1,960 & 23.0 & 70.9 \\
2 & 7,150 & 667 & 3,423 & 56.2 & 2,644 & 22.7 & 66.2 \\
3 & 4,964 & 667 & 2,372 & 57.9 & 1,840 & 22.4 & 67.3 \\
Average & 5,998 & 667 & 2,757 & 58.8 & 2,130 & 22.7 & 68.1 \\
\hline
\end{tabular}

${ }^{1)}$ Weight loss- $1(\%)$ by $(1-[C /\{A+B\}]) \times 100$ for 3 months staying in the barn.

${ }^{2)}$ Weight loss-2 (\%) by $(1-D / C) \times 100$ for 1 month storing in the composting lot.

${ }^{3)}$ Total weight loss by $(1-[D /\{A+B]]) \times 100$ for 4 months including both periods.

was stored in a composting lot for 1 month. The total reduction in weight was measured for 4 months, for which 3 months the manure was in the barn and 1 in the composting lot (Table 3). A final value of mixture weight loss of $58.8 \%$ was observed while the mixture of dairy cattle manure and bedding materials left in cattle barns for 3 months. For this experiment, the entire mixtures of manure and bedding materials were weighed from cattle barns, after which point the mixture was stored in a composting lot for 1 month, resulting in weight loss of $22.7 \%$. The overall weight loss of the mixture was $68.1 \%$ for 4 months.

The amount of $\mathrm{P}$ before and after composting should not change theoretically without the leachate occurrence or run-off since all of the $\mathrm{P}$ remains in the compost pile in the form of ortho- or poly-phosphate in addition to other organic compounds. Thus, the weight reduction can be calculated as is described below and the weight loss of $60 \%$ on average was derived based on the constant $\mathrm{P}$ content as was revealed by case III (Table 4). It was found that weight loss was higher in the field study (68\%) compared to the database from the Ministry of Environment (55\%) or where P loss was zero (60\%).

\section{Weight loss (\%)}

$$
=\left[1-\frac{[\mathrm{P}]_{\text {in mixture of manure \& bedding materials }}}{[\mathrm{P}]_{\text {in compost }}}\right] \times 100
$$

Where $[\mathrm{P}]$ indicates the concentration of $\mathrm{P}$.

\section{Calculation of nutrient loading coefficients}

According to the data from cases related to weight reduction, the NLCs for VS, TN, and TP were calculated based on the nutrient concentrations from sample analyses (Table 5). The

Table 4. Weight reduction of dairy cattle manure during storing and composting periods according to three cases

\begin{tabular}{lc}
\hline Cases & Weight reduction (\%) \\
\hline I) $^{1)}$ & $68 \pm 10$ \\
II & $55 \pm 12$ \\
III & $60 \pm 16$ \\
\hline
\end{tabular}

${ }^{11}$ Weight reduction cases: I, Experiment; II, Reference; III, $\Delta P=0$ before and after composting.
NLCs refer to the nutrient amount from the manure to be loaded on land and nutrient loss is the opposite means of NLCs as previously described.

According to case II, higher NLCs were found for VS (1.92), $\mathrm{TN}(0.78)$ and TP (0.84) whereas, the values of NLCs in case I were $1.48,0.60$, and 0.66 for VS, TN, and TP, respectively. The values of NLCs based on a reference based weight reduction might be overestimated compared to the practical investigation of this experiment. Considering agricultural land excluding $\mathrm{N}$ emission to atmosphere, case III could be a reasonable value to determine the impacts of nutrients from dairy cattle manure in Korea. However, with respect to the nutrient loading only on agricultural land as soil budget for nutrients, the values of NLCs in case I would be reasonable.

\section{DISCUSSION}

\section{Characteristics of dairy cattle manure and compost}

Since we found that the average moisture contents of cattle manure and bedding materials were approximately $81.6 \%$ and $20.0 \%$, respectively, $11.5 \mathrm{~kg}$ bedding material/head/ $\mathrm{d}$ is required to obtain an optimal moisture content for composting (approximately 65\%) assuming an average daily manure production of $37.7 \mathrm{~kg} / \mathrm{d}$ as obtained from the Ministry of Environment document $[15,16]$. However, most dairy farmers used only $1.03 \mathrm{~kg} / \mathrm{head} / \mathrm{d}$ of bedding materials on average across the existing management practices. Assuming that there were no other factors affecting the mixture, such as ambient drying and the addition of water, the moisture content in the mixture

Table 5. The nutrient loading coefficients for VS, TN, and TP from dairy cattle manure according to three cases

\begin{tabular}{lccc}
\hline \multirow{2}{*}{$\begin{array}{l}\text { Cases for weight loss during } \\
\text { the composting or storing period }\end{array}$} & \multicolumn{3}{c}{ Nutrient loading coefficients } \\
\cline { 2 - 4 } & VS & TN & TP \\
\hline I) & 1.48 & 0.60 & 0.66 \\
II & 1.92 & 0.78 & 0.84 \\
III & 2.29 & 0.87 & - \\
Average & 1.90 & 0.75 & 0.75 \\
\hline
\end{tabular}

VS, volatile solids; TN, total nitrogen; TP, total phosphorus.

${ }^{1)}$ Weight reduction cases: I, Experiment; II, Reference; III, $\Delta \mathrm{P}=0$ before and after composting. 
was predicted to be $79.7 \%$ with the investigated amount of bedding materials used $(1.03 \mathrm{~kg} / \mathrm{head} / \mathrm{d})$. This highly moistened condition inhibited oxygen dispersal and thereby dead zones (anaerobic condition) were formed in the static piles [17]. Composting piles under anaerobic conditions take longer to decompose and a temperature of $55^{\circ} \mathrm{C}$ cannot be reached for pathogen destruction, which results in lower compost qualities [18]. The moisture content decreased naturally in the cattle barn; however, it was not possible to reach the optimal moisture level of $65 \%$ only with ambient drying and the amount of bedding materials investigated. In order to perform composting normally on dairy farms, sufficient bedding materials are required with the sufficient budget. Thus, frequent turning of the composting pile may help decrease the moisture content. Higher concentrations of TN, TP, and VS in dairy cattle manure after storage and composting might be due to the reduction in moisture content and the components that were condensed with weight loss $[19,20]$. Sommer [7] also found a higher TP concentration (34\%) in cattle manure after 132 days of composting. This might have occurred due to moisture reduction and organic matter degradation during composting.

\section{Construction of weight reduction cases during the composting period}

The previous case II from the study by Cooperband [10] revealed that volume reductions of $55 \%, 73 \%$, and $55 \%$ of cattle manure occurred when utilizing the composting methods of simple static pile, windrow or turning, and aeration, respectively. In the present study, 36 farms used the simple static and 5 utilized the turning pile method and the weight reduction of each farm was calculated from the volume reduction using the bulk density of the samples. Weight reduction occurred due to moisture loss and microbial degradation during the composting period. Although the majority of the existing management practices followed a simple static pile method (88\%), aerobic turning was also used (12\%), and in the instances where there was a higher weight reduction (68\%) than expected, it could have been due to low humidity, temperature, or other environmental causes. Average organic matter degradation was measured to be $53.3 \%$ of the total in each experiment during the 4 months of storage and composting and might be due to processes, including $\mathrm{CO}_{2}, \mathrm{CH}_{4}$, and $\mathrm{N}_{2} \mathrm{O}$ emission, as well as $\mathrm{NH}_{3}$ volatilization, nitrification, and denitrification due to the action of microbes. Further, complex compounds in manure were transformed into their most simple and stable forms during the composting process.

\section{Calculation of nutrient loading coefficients}

The larger values of NLCs for VS (1.48 to 2.29) were produced by the addition of bedding materials. The lower TN ( 0.60 to 0.87 ) values indicated that $13 \%$ to $40 \%$ of this element was reduced, presumably by ammonia volatilization, nitrous oxide,
$\mathrm{N}$ gas emission and leachate [6,21-23]. Except for in case III, where no change in $\mathrm{P}$ concentration was observed, the reduction of TP was $34 \%$ and $16 \%$ in cases I and II, respectively. Theoretically, changes in $\mathrm{P}$ concentration occur if there is leachate or run-off. In this regard, case III may be the best for the calculation of total nutrient loading only excluding nutrient emission to atmosphere. However, the TN reduction in case III was only $13 \%$, which indicates that most of the TN is retained in compost and ultimately imparted to the land. Inactive composting might cause such a low reduction of TN, which meant that no turning had taken place or there was insufficient addition of bedding material. The nutrient reduction via composting dairy cattle manure was previously reported as VS values from $29 \%$ to $81 \%$ and TN from $5 \%$ to $43 \%$, although it was dependent upon the regional climate and composting methods [24-27]. Therefore, the values of NLCs obtained (VS, 1.48; TN, 0.60 ; TP, 0.66 ) from Case I experiment may accurately reflect the nutrient loading on agricultural land. Combining these derived NLCs with the data from the statistical report in Korea, the amounts of TN and TP from dairy cattle to agricultural land would be 15,262 and 5,882 tons per year, respectively, based on a dairy cattle population of 430,678 heads [14]. However, without considering nutrient loss during composting or storage, the nutrient values in manure would be directly applied to the yearly production of nutrients resulting in 25,437 tons of TN and 8,912 tons of TP, which are values 1.6 and 1.5 fold higher, respectively.

Although in the present study, we took into account the characteristics of manure and compost, utilization of bedding materials, and weight reduction during the storage and composting periods, and found that cattle manure is often mixed with insufficient amounts of bedding materials, then stacked in the composting lot without proper handling or even sufficient time before being applied to land as fertilizer, which causes an increased nutrient loading on soil and unpleasant odour in the surrounding areas. It has been proven that cattle manure needs a longer time for decomposition compared to pig or poultry due to the presence of large amount of fibrous materials [28]. Less usage of bedding material lowers the porosity in the composting pile, leading to an insufficient air supply and microbial degradation of the mixture during composting, and ultimately in high moisture in the dairy cattle manure compost in Korea. Addition of sufficient bedding materials in the dairy barn and longer composting periods along with aeration and turning are necessary to increase the compost quality of dairy cattle manure, which may ensure lower NLCs. Thus, it is mandatory and urgent to improve the management of dairy cattle manure in Korea.

Consequently, to calculate the amount of nutrients with respect to soil budget which are being loaded on agricultural land, it is desirable to use the NLCs values, [VS, 1.48; TN, 0.60; TP, 0.66] obtained from this experiment regarding soil $\mathrm{N}$ budget. 
The NLCs developed here may be helpful for manure handling practices and beneficial for their application in agricultural land management as well as for the accurate calculation of nutrient in soil budget.

Further, when compared with animal heads in livestock categories, the number of dairy cattle occupies only $3 \%$ but $12.9 \%$ in the contribution of manure production as previously mentioned, which indicates dairy cattle produces the highest amount of manure per head as previously mentioned. The management of dairy cattle manure is more difficult than for the manure of other livestock categories due to its high moisture content. This is paradoxical since swine manure is characterized by higher moisture content than dairy cattle manure. However, most swine farms in Korea have solid and liquid separators while dairy farms do not, which results in relatively higher cost for purchasing bedding materials on dairy farms. Thus, the development of methods or protocols to decrease the moisture content in dairy cattle manure for proper composting is necessary and utilization is required in the near future.

\section{CONFLICT OF INTEREST}

We certify that there is no conflict of interest with any financial organization regarding the material discussed in the manuscript.

\section{ACKNOWLEDGMENTS}

This study was financially supported by the Rural Development Administration Project (grant number PJ011623), Korea, and the authors also wish to acknowledge the support of Kangwon National University. Thanks are extended to dairy farms who supplied the samples and their cooperation.

\section{REFERENCES}

1. Burton CH, Turner C. 2003. Manure Management: Treatment Strategies for Sustainable Agriculture. 2nd ed. Silsoe Research Institute, Bedford, UK: Lister and Durling Printers; 2003.

2. Khan FA, Ansari AA. Eutrophication: An ecological vision. Bot Rev 2005;71:449-82.

3. Eurostat. Nutrient Budgets - Methodology and Handbook. Luxembourg: Eurostat and OECD; 2013. Version 1.02.

4. MARFA (Ministry of Agriculture, Food and Rural Affairs): Outcome of animal waste generation and recycling [Internet]. Korean Government Printing Office; 2013. Available from: http://mafra. go.kr/list.jsp?newsid=155444621\&section_id=b_sec_1\&listcnt= $5 \&$ pageNo=1\&year=\&group_id=3\&menu_id=1125\&link_menu_ $\mathrm{id}=\&$ division=B\&board_kind=C\&board_skin_id=C3\&parent_ code $=3 \&$ link_url=\&depth $=1$

5. Gao C, Sun B, Zhang TL. Sustainable nutrient management in Chinese agriculture: challenges and perspective. Pedosphere 2006; 16:253-63.
6. Eghball B, Power JF, Gilley JE, Doran JW. Nutrient, carbon, and mass loss during composting of beef cattle feedlot manure. J Environ Qual 1997;26:189-93.

7. Sommer SG. Effect of composting on nutrient loss and nitrogen availability of cattle deep litter. Eur J Agron 2001;14:123-33.

8. Song JH, Kim CG, Huh D, Lim SJ. A study on the introduction of regional maximum load system of livestock numbers. Seoul, Korea: Korea Rural Economic Institute; 2004. Research report. p. 24.

9. APHA (American Public Health Association). Standard Methods for the Examination of Water and Wastewater. 19th ed. Washington, DC: American Public Health Association, American Water Works Association and Water Environment Federation; 1995.

10. Cooperband L. The Art and Science of Composting: A resource for farmers and compost producers. University of WisconsinMadison, WI: Center for Integrated Agricultural Systems; 2002.

11. Ministry of Environment [Internet]. Major Policies. Water Environment Policy Bureau; 2013 [cited 2015 Mar 31]. Available from: http://www.me.go.kr/home/web/policy_data/read.do?page rOffset $=0 \&$ maxPageItems $=10 \&$ maxIndexPages $=10 \&$ searchKey $=$ title\&searchValue $=\% \mathrm{EA} \% \mathrm{~B} 0 \% 80 \% \mathrm{EC} \% \mathrm{~B} 6 \% 95 \% \mathrm{~EB} \% \mathrm{~B} 6 \% 84 \%$ $\mathrm{EB} \% 87 \%$ A8\&menuId=10259\&orgCd=\&seq $=5067$

12. Ministry of Government Legislation [Internet]: National Law Information Center; 2015 [cited 2015 Feb 24] Available from: http://www.law.go.kr/\%ED\%96\%89\%EC\%A0\%95\%EA\%B7\%9C \%ЕC\%B9\%99/\%EA\%B0\%80\%ЕC\%B6\%95\%ЕC\%82\%AC\%ЕC\% 9C\%A1\%EC\%8B\%9C\%EC\%84\%A4\%20\%EB\%8B\%A8\%ЕC\%9 C\%84\%EB\%A9\%B4\%EC\%A0\%81\%EB\%8B\%B9\%20\%EC\%A0\%81\%ЕC\%A0\%95\%20\%ЕA\%B0\%80\%ЕC\%B6\%95\%ЕC\%82\%AC \%ЕC\%9C\%A1\%ЕA\%B8\%B0\%ЕC\%A4\%80

13. Vadas PA, Busch DL, Powell JM, Brink GE. Monitoring runoff from cattle-grazed pastures for a phosphorus loss quantification tool. Agric Ecosyst Environ 2015;199:124-31.

14. Statistics Korea [Internet]. National Index System. 2015 [cited 2015 Mar 24]. Available from: http://www.index.go.kr/potal/main/ EachDtlPageDetail.do?idx_cd=1287

15. Rynk R, van de Kamp M, Willson GB, et al. On-Farm Composting Handbook. Ithaca, NY: Northeast Regional Agricultural Engineering Service; 1992.

16. Keener HM, Pecchia JA, Reid GL, Michel FC, Elwell DL. Effects of aeration and covers on $\mathrm{NH} 3$, water and dry matter loss during windrow composting of dairy manure. St Joseph, MI: ASAE; 2000. Paper No. 024139.

17. Das K, Keener HM. Moisture effect on compaction and permeability in composts. J Environ Eng 1997;123:275-81.

18. USDA (United States Department of agriculture). National Organic Program Standards. Washington, DC: US Government Printing Office; 2002. Rule 7 CFR Part 205 (RIN: 0581-AA40).

19. Bernal MP, Navarro AF, Roig A, Cegarra J, Garcia D. Carbon and nitrogen transformation during composting of sweet sorghum bagasse. Biol Fertil Soils 1996;22:141-48.

20. Paredes C, Bernal MP, Cegarra J, Roig A, Navarro AF. Nitrogen 
transformation during the composting of different organic wastes. Progress in Nitrogen Cycling Studies; 1996:68 of the series Developments in Plant and Soil Sciences. pp. 121-5.

21. Dewes T. Ammonia emissions during the initial phase of microbial degradation of solid and liquid cattle manure. Bioresour Technol 1999;70:245-48.

22. Barrington S, Choiniere D, Trigui M, Knight W. Effect of carbon source on compost nitrogen and carbon losses. Bioresour Technol 2002;83:189-94.

23. Gibbs PA, Parkinson RJ, Misselbrook TH, Burchett S. Environmental impacts of cattle manure composting. In: Insam H, Riddech N, Klammer S, editors. Microbiology of composting. Springer, NY; 2002.

24. Changa CM, Wang P, Watson ME, Hoitink HAJ, Michel FC Jr.
Assessment of the reliability of a commercial maturity test kit for composted manures. Compost Sci Util 2003;11:125-43.

25. Frederick C, Michel Jr, Pecchia JA, Rigot J, Keener HM. Mass and nutrient losses during the composting of dairy manure amended with sawdust or straw. Compost Sci Util 2004;12:323-34.

26. Liang Y, Leonard JJ, Feddes JJR, McGill WB. Influence of carbon and buffer amendment on ammonia volatilization in composting. Bioresour Technol 2006;97:748-61.

27. Larney FJ, Hao X. A review of composting as a management alternative for beef feedlot manure in southern Alberta, Canada. Bioresour Technol 2007;98:3221-7.

28. Graves RE, Hattemer GM, Stettler D. Composting. In: Environmental engineering national engineering handbook. National Engineering Handbook, USDA. 2000. Part 637. 